is to increase the alkalinity of the blood is based Dr. Haig's entire theory of the cause of fatigue-a theory that seems to be completely borne out by the experiments he adduces. But in the article which follows, "The Clinical E-timation of the Alkalinity of the Blood," Dr. Hutchison makes the following explicit assertion: "The effect of severe muscular work is to cause a fall in the alkalinity of the blood, this being probably due to the production of consider. able quantities of lactic acid by muscular metabolism." How can these two statements be reconciled? Dr. Haig, it will be seen, attributes the rise in the alkalinity to the increased excretion of acids by the skin, while Dr. Hutchison thinks that the reverse result is probably due to the production of lactic acid by muscular metabolism. Which is the correct view? As I have said before, I can lay claim to absolutely no qualification that would entitle me to express any opinion upon the subject, but the question as to what really is the effect of muscular work upon the alkalinity of the blood is one of such great interest and importance that I may possibly be excused for calling attention to it in this instance.

March 16th 1890 I am, Sirs, yours faithfully, W. B. Fotheringham.

\section{"THE NEW INFANTRY SWORD EXERCISE."} To the Editors of THE LANCET.

SiRs,-In a letter published in Trie LANCET of March 28th Dr. Ritchie takes exception to my criticisms, ${ }^{1}$ founded on anatomical and physiological grounds, of the new infantry sword exercise. With your permission I will reply briefly to the points he raises. I endeavoured to show that in the Masiello system-a more accurate term, I understand, than "Italian" for the newly-adopted exercise-a greater expenditure of force is necessary to effect the required movements than in the French system; that fatigue, in consequence, will ensue earlier; that the chief muscles concerned have to act at an undue mechanical disadvantage; and that rapidity, variety, and delicacy of movement are to a great extent sacrificed in order to ensure a more powerful thrust. It does not appear to me that Dr. Ritchie effectively traverses these propositions. With regard to the "on guard" position, Dr. Ritchie argues that the wider separation of the feet in the Masiello attitude allows greater rapidity in the "advance" and "retire," because a greater pressure can be exerted in the left foot in the "advance" and from the rioht in the "retire." I cannot agree with him. The more the feet are separated the greater is the exertion necessary in the initial stage of either movement and the less perfect is the balance. Additional exertion is therefore required to preserve the balance. If we accept Dr. Ritchie's view it should follow that with the feet still more widely separated than is prescribed in the Masiello "on guard" position the movements of "advance" and "retire" are still further facilitated. We are then brought face to face with a very obvious reductio ad absurdum. Dr. Ritchie admits frankly the greater exertion needed when he writes that the advantage of "greater rapidity of movement backwards from the Italian than from the French attitude" (retiring) is "well worth the extra effort entailed by the further separation of the feet." But to my mind the removal of the resistance of the left foot in retiring leads not to greater rapidity of movement so much as to loss of balance. The further the supporting leg (in this case the right) is from the line of gravity passing through the trunk, the less perfect is the balance and the greater is the effort required to maintain it. Comparisons of diagrams of the Masiello and French attitudes will make this point obvious at once. The greater the exertion the more quickly will fatigue ensue.

Next, as to recovery from the lunge. Dr. Ritchie considers that the raising of the body to the vertical position is effected by the hamstring muscles rather than by the gluteals, as I stated. I think this criticism is sound. I noticed the error before my letter appeared in print, but when it was too late to correct it. The correction makes my case stronger. It is unnecessary for me to call attention again to the mechanical disadvantage under which the hamstring muscles act and the clisproportion between the two arms of the lever, for Dr. Ritchie himself points this out very clearly. As the muscles act at such a mechanical disadvantage the expenditure of force necessary to effect the recovery is very

1 The Lancet, Nov. 30th, 1895. great, far greater than in the recovery from the French lunge. And for the same reason the initial velocity of the backward swing is comparatively low. By "backward swing," it must be noted, is meant the raising of the body from the inclined position forwards to the vertical attitude. beyond this the body is not allowed to swing. The chief function of the erector spinæ in this action is to preserve the rigidity of the longer arm of the lever. To the opinion that the backward swing does not increase the rapidity of recovery I must still adhere. The experiment mentioned by Dr. Ritchie only illustrates the greater force needed in recovery from the Masiello lunge. The extra exertion and the consequent fatigue again are practically conceded. Dr. Ritchie makes no allusion to the fatigue entailed on the sword arm by the extended position of the limb in the " on guard" position, and I may take it, therefore, that he concedes this point also, which, indeed, it seems impossible to question. He does not deal with the remarks I made on the movements of pronation and supination on the ground that in the Masiello system these movements are not concerned, supination being only required in one of the parries; that is to say, that all the advantages to be obtained in the French system from the various movements of the fingers and the artions of pronation and supination are thrown away in the Masiello method. The greater variety of movements, and the fact that they can be made with less expenditure of force and so entail less fatigne, seem to me, on anatomical and physiological grounds, to make the French system incomparably the more scientific of the two. I am, Sirs, yours faithfully,

Brook-street, W., April 6th, 1896.

C. T. DENT.

\section{THE SANITARY INSTITUTE AND THE ISOLATION OF CASES OF INFECTIOUS DISEASE IN THE METROPOLIS. \\ To the Editors of THE LANCET.}

Sins,- The interesting paper on the above subject read at the sessional meeting on March 11 th by Mr. Augustus Charles Scovell could not have failed to impress the audience wirh the importance of this subject as regards the protection of the public against zymotic diseases and consequently the reduction of the death-rate. But while I deeply appreciated the interesting discussion and the important contribution thereto by the eloquence of $\mathrm{Dr}$. Thorne Thorne I was disappointed that little or nothing was said as to the working of the Notification Act. My presence as a guest made me feel some diffidence as to the etiquette of personally calling attention to the subject, the importance of which alone justifies my now drawing attention to it. $\mathrm{Mr}$. Scovell, in speaking of scarlet fever in connexion with the future demands for hospital accommodation, said that "the accumulating statistics of notification ought to prove useful." And it is to this disease alone that I shall confine my comments. Mr. Scovell is right, but I feel sure as long as the Act remains as it is, and as long as even its present provisions are not strictly carried out, the Metropolitan Asylums Board will not benefit by the collected statistics as much as they desire, nor will the disease become less prevalent; nay, even the contrary effect will be produced. I am confident that the Act is not thoroughly carried out and that it wants amending so that the full benefit it was intended to convey to the public may be secured. I would ask, first, why is the Act not strictly carried out ? and, secondly, what defect, if any, conduces to render it incompetent to deal with this disease as we all desire?

Now, Sirs, in answer to the first question I would say that the Act places a penalty on the head of the family which might become so severe that he deliberately, and perhaps not unnaturally, tries to avoid coming under its provisions; and owing to the notification having in many instances to go to an opposing general practitioner it is felt to be a grievance in provincial towns - where there is much prejudice against employing a medical man who is known to be in attendance on a patient suffering from an infectious disesse-that one practitioner should be placed in possession of information that sooner or later leaks out (not by the medical officer of bealth divulging information he has officially received) and which will bring temporary loss on the notifying practitioner. That part of the question relating to the head of the family is by far the more serious. No medical man would abstain 